\title{
A silent mutation, C924T (G308G), in the L1CAM gene results in $\mathrm{X}$ linked hydrocephalus (HSAS)
}

\author{
Yang-Zhu Du, Cheryl Dickerson, Arthur S Aylsworth, Charles E Schwartz
}

\begin{abstract}
The $L 1$ cell adhesion molecule (L1CAM) is a neuronal gene involved in the development of the nervous system. Mutations in L1CAM are known to cause several clinically overlapping $X$ linked mental retardation conditions: $X$ linked hydrocephalus (HSAS), MASA syndrome (mental retardation, aphasia, shuffling gait, adducted thumbs), spastic paraplegia type I (SPG1), and $X$ linked agenesis of the corpus callosum (ACC). In an analysis of a family with HSAS, we identified a $C \rightarrow T$ transition (C924T) in exon 8 that was initially thought to have no effect on the protein sequence as the alteration affected the third base of a codon (G308G). Extensive analysis of the other 27 exons showed no other alteration. A review of the sequence surrounding position 924 indicated that the $\mathbf{C} \rightarrow \mathbf{T}$ transition created a potential $5^{\prime}$ splice site consensus sequence, which would result in an in frame deletion of 69 bp from exon 8 and 23 amino acids of the LICAM protein. RT-PCR of the RNA from an affected male fetus and subsequent sequence analysis confirmed the use of the new splice site. This is the first report of a silent nucleotide substitution in L1CAM giving rise to an alteration at the protein level. Furthermore, it shows that as mutation analysis plays an ever more important role in human genetics, the identification of a synonymous base change should not be routinely discounted as a neutral polymorphism.

$(\Im$ Med Genet 1998;35:456-462)
\end{abstract}

Keywords: silent mutation; L1CAM; restriction endonuclease fingerprinting (REF); cryptic splice site

Rosenthal et $a l^{1}$ were the first to present evidence for the involvement of a mutation of the $\mathrm{L} 1$ cell adhesion molecule (L1CAM) in X linked hydrocephalus. The finding was consistent with linkage analyses which placed both L1CAM and X linked hydrocephalus resulting from stenosis of the aqueduct of Sylvius (HSAS) in Xq28, ${ }^{2}$ and studies that had implicated L1CAM in neurite outgrowth. ${ }^{4}$ Subsequently, mutations in this neuronal glycoprotein were found to cause other disorders clinically related to $\mathrm{X}$ linked hydrocephalus, such as MASA syndrome (mental retardation, aphasia, shuffling gait, adducted thumbs), $\mathrm{X}$ linked spastic paraplegia type I (SPG1), and X linked agenesis of the corpus callosum
(ACC)..$^{56}$ At present, there are over 50 L1CAM mutations listed on the L1 Mutation Web Page. ${ }^{7}$ Approximately $75 \%$ of the mutations are contained within 19 exons that represent $65 \%$ of the coding sequence. ${ }^{8}$ These mutations include frameshifts, missense mutations, stop codons, and alterations in splice site junctions. In almost every case, a mutation appears limited to a single family. In a few instances, the same mutation will give rise to more than one of the above clinically related genetic disorders, so that one can observe both inter- and intrafamilial variability in families with L1CAM mutations. ${ }^{8-10}$

As part of our interest in $\mathrm{X}$ linked mental retardation, we have been investigating families with HSAS and MASA. As expected, we have observed the range of mutations in L1CAM mentioned above. ${ }^{8}$ However, in one family with a history of HSAS over four generations, we were unable to detect any mutation other than a presumed silent alteration at position 924 in which a $\mathrm{C} \rightarrow \mathrm{T}$ transition affected the third position in a glycine codon (G308G). We present evidence that this neutral mutational event is, in fact, the cause of HSAS as a result of the creation of an alternate 5 ' splice site.

\section{Materials and methods \\ CLINICAL FINDINGS}

Case report

The proband (IV.1) had severe congenital hydrocephalus associated with apparent aqueductal stenosis; he received a shunt at 4 days of age. The remaining cortex was very thin. His head circumference was within the normal range at 3 months and was almost 1 SD below the mean at 4 years 8 months. At the age of 7 years, a head MRI showed agenesis of the corpus callosum and hydrocephalus. His hands were held tightly clenched with the thumbs and the third finger overlapping the second finger. All fingers could be straightened passively except the index fingers which were held tightly contracted in the palms. The thumbs could be extended more easily than the index fingers. Therefore, he appeared to have adducted/ contracted index fingers rather than the adducted thumb position that is sometimes associated with HSAS.

\section{FAMILY HISTORY}

Four maternal great uncles died at birth or in early infancy with congenital hydrocephalus; they were brothers of the maternal grandmother (fig 1A). Clinical information is not available, but they were described by the family 


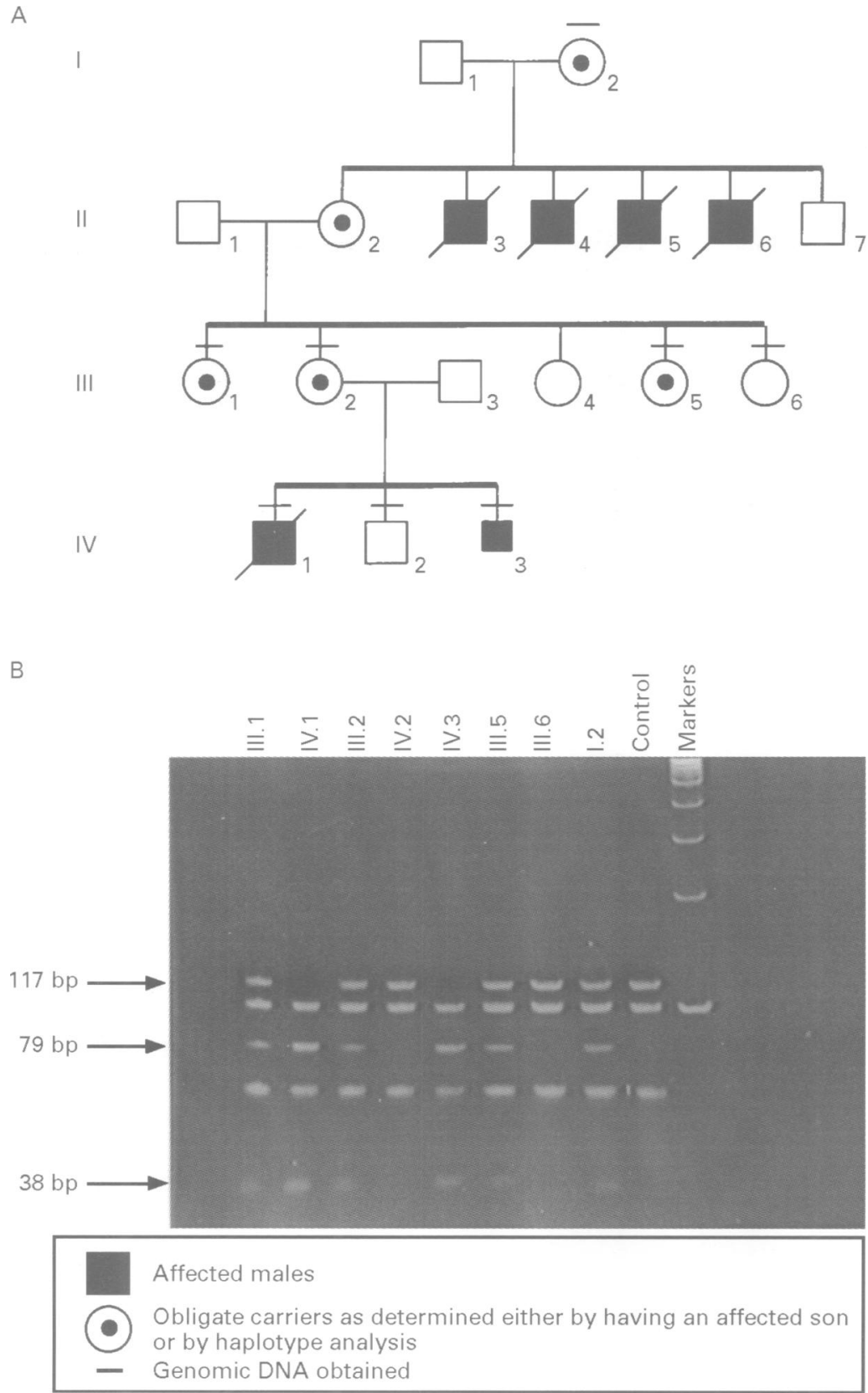

Figure 1 (A) Pedigree of kindred K8715 with HSAS. (B) HphI analysis of the C924T alternation in kindred K8715. The unaffected chromosome contains a $117 \mathrm{bp}$ fragment. A chromosome with the C924T alteration contains an HphI site in the $117 \mathrm{bp}$ fragment which upon digestion gives rise to two fragments of $79 \mathrm{bp}$ and $38 \mathrm{bp}$, respectively. Notation above the lane gives the location in the pedigree in $(A)$.

as looking like the proband. This family is family 7 in the report by Willems et al. ${ }^{2}$

\section{GENOMIC DNA}

Blood or amniocytes were obtained with informed consent. Genomic DNA was isolated from peripheral blood using a high salt method. ${ }^{11}$ DNA from amniocytes was prepared using routine procedures. ${ }^{12}$

\section{RESTRICTION ENDONUCLEASE FINGERPRINTING} (REF)

Exons 7-10 were amplified as a 1088 bp fragment using the following primers: ex7-10f: 5'CTGGGGTGGAGGGAAGAGTG3', ex710r: 5'CCAGTGGGTGCAGGGACAGA3'. The PCR reaction mixture contained 10 $\mathrm{mmol} / 1$ Tris- $\mathrm{HCl}, \mathrm{pH} 8.3,50 \mathrm{mmol} / 1 \mathrm{KC} 1,1.5$ $\mathrm{mmol} / 1 \mathrm{MgCl}_{2}, 50 \mu \mathrm{mol} / \mathrm{l}$ of each dATP, dCTP, dGTP, dTTP, $1 \mu \mathrm{mol} / 1$ of each primer, $2.5 \mathrm{U}$ of
Taq DNA polymerase (BoehringerMannheim), $0.55 \mu \mathrm{g}$ TaqI polymerase start antibody (Clontech), and $125 \mathrm{ng}$ genomic DNA in a $50 \mu 1$ total volume. The initial denaturing temperature was $94^{\circ} \mathrm{C}$ for five minutes. This was followed by 35 cycles of denaturation at $94^{\circ} \mathrm{C}$ for 30 seconds, annealing at $70^{\circ} \mathrm{C}$ for one minute, and extension at $72^{\circ} \mathrm{C}$ for 1.5 minutes, followed by a final extension at $72^{\circ} \mathrm{C}$ for 10 minutes. The PCR products were checked by $1.5 \%$ agarose gel electrophoresis before doing REF.

A total of $100 \mathrm{ng}$ of the exons 7-10 PCR product were digested separately by four different restriction endonucleases in a total volume of $10 \mu \mathrm{l}$. The four digestion reactions contained $4 \mathrm{U}$ HhaI in NEB buffer 4 , or $4 \mathrm{U}$ DdeI in NEB buffer 3, or $4 \mathrm{U} H$ HinfI, or $4 \mathrm{U}$ $M s p \mathrm{I}$ in NEB buffer 2 , and $0.4 \mathrm{U}$ CIAP at $37^{\circ} \mathrm{C}$ for 12 hours. 


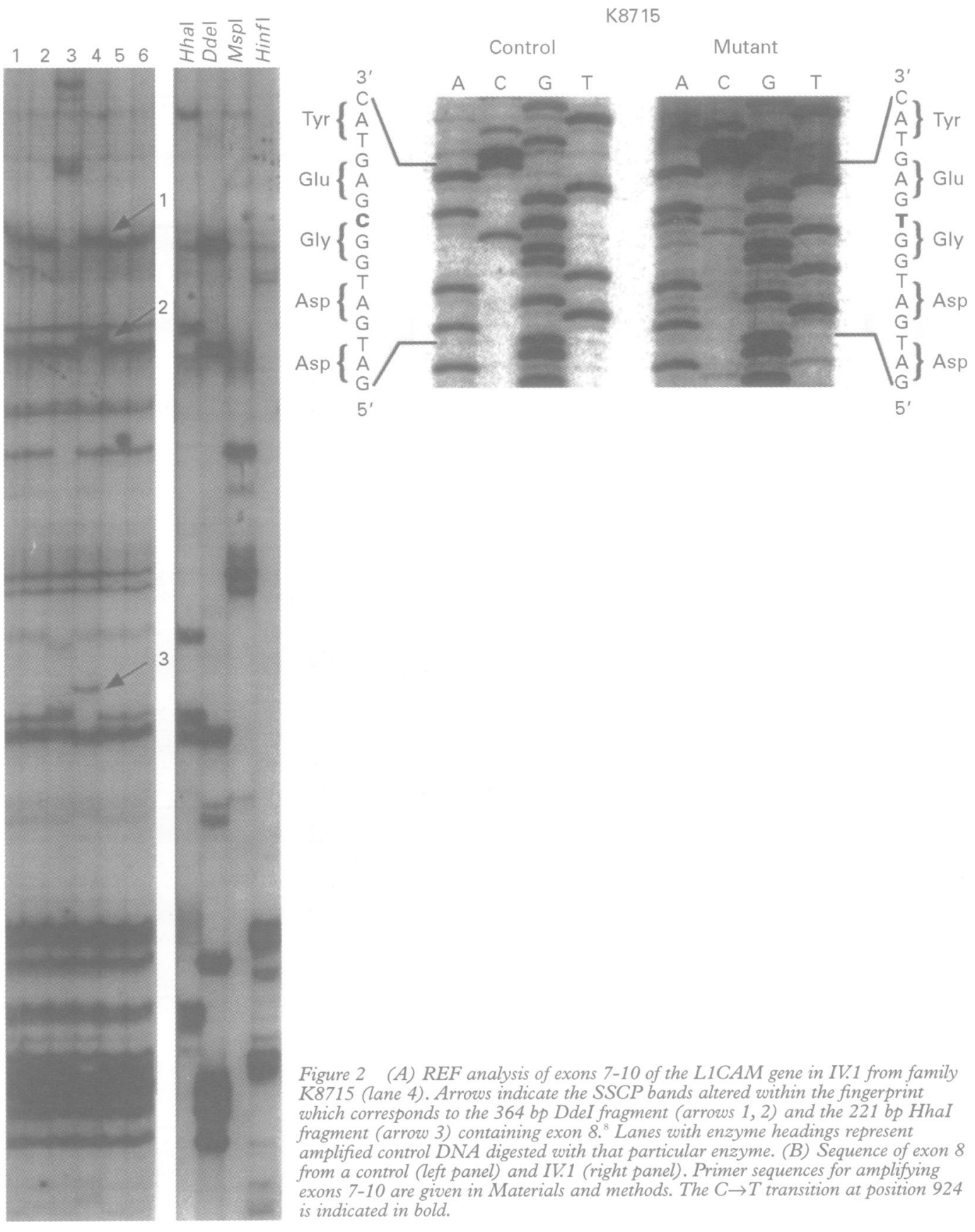

After digestion, all the endonucleases were inactivated at $96^{\circ} \mathrm{C}$ for 10 minutes. The several reactions were mixed together and reheated at $96^{\circ} \mathrm{C}$ for five minutes. Digested fragments $(10$ ng) were incubated with $6 \mu \mathrm{Ci} \gamma-{ }^{32} \mathrm{P}$ ATP and 1 $\mathrm{U}$ T4 kinase in a buffer of $70 \mathrm{mmol} / 1 \mathrm{Tris}-\mathrm{HCl}$, $\mathrm{pH} 7.6,10 \mathrm{mmol} / 1 \mathrm{MgCl}_{2}, 5 \mathrm{mmol} / \mathrm{l} \mathrm{DTT}$ at $37^{\circ} \mathrm{C}$ for three hours. After the labelling reaction, $10 \mu \mathrm{l}$ stop buffer ( $95 \%$ formamide, 10 $\mathrm{mmol} / \mathrm{l} \mathrm{NaOH}, 0.25 \%$ bromophenol blue, $0.25 \%$ xylene cyanol) were added to each tube and $4 \mu \mathrm{l}$ were loaded onto either a $6 \%$ acrylamide gel or a MDE (FMC) gel separately. The $6 \%$ acrylamide gel contained $10 \%$ glycerol and $0.6 \times \mathrm{TBE}$ and was run at $8 \mathrm{~W}$, $4^{\circ} \mathrm{C}$ for 24 hours. The MDE gel was prepared according to the FMC instruction manual and run at $8 \mathrm{~W}$ at room temperature for 12 hours. The gels were dried and exposed to Biomax film (Kodak, Rochester, NY, USA) at $-80^{\circ} \mathrm{C}$ for 1.5 hours.

SEQUENCING OF PCR PRODUCTS

PCR products $(50 \mu \mathrm{l})$ were run on $1 \%$ agarose gels containing $1 \times \mathrm{TBE}$. The DNA bands were cut out and DNA was purified using QIAquick gel extraction kit (Qiagen). DNA sequencing was performed using the fmol DNA sequencing system (Promega). $\alpha{ }^{33} \mathrm{P}$ dATP or $\alpha{ }^{-35} S$ dATP were used in sequencing reactions and $3 \mu \mathrm{l}$ of sequencing reaction was run on $6 \%$ polyacrylamide gel containing $7 \mathrm{~mol} / \mathrm{l}$ urea at $85 \mathrm{~W}$ for three to six hours.

DETECTION OF HPhI POLYMORPHISM

Template DNA (100 ng) from peripheral blood was PCR amplified in a $40 \mu$ l volume using primers G10 and G11 (23), which flank 
A Normal

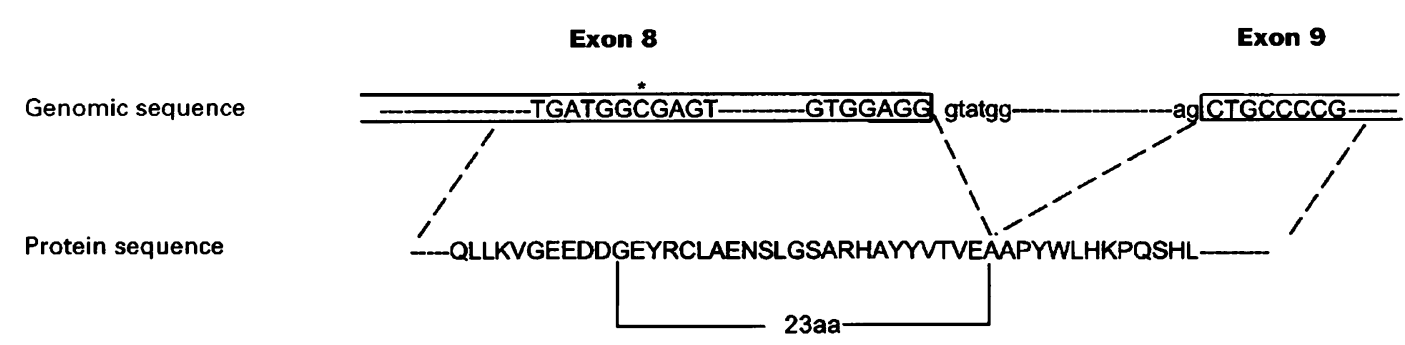

B K8715

Genomic sequence

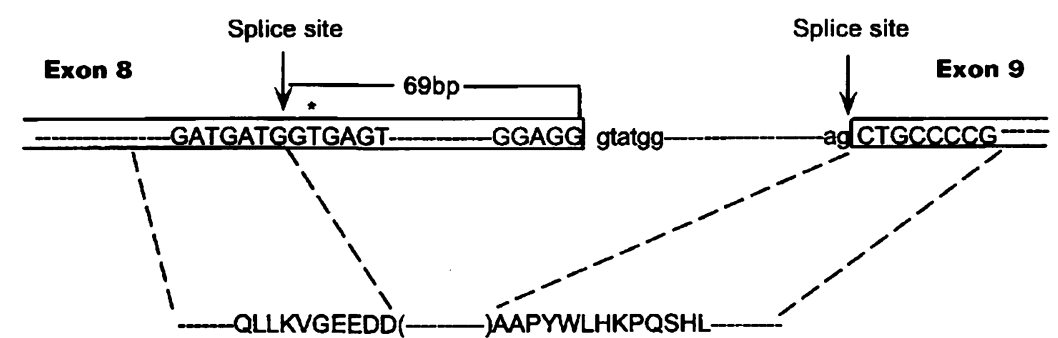

Protein sequence

Figure 3 Schematic representation of exon 8, intron 8, exon 9 organisation in L1CAM. (A) Normal genomic sequence near the exon 8/intron 8 and intron 8/exon 9 boundaries. Protein sequence of the L1CAM gene corresponding to this coding region is given below the genomic sequence. (B) Genomic sequence for same region in the X chromosome in K8715 which carries the C924T alteration. The predicted amino acid sequence for the altered L1CAM protein is given below the genomic sequence. The new 5' splice site is indicated by an arrow. In both $(A)$ and $(B)$, position 924 is indicated by *.

exon 8 of the L1CAM gene. The reaction contained $10 \mathrm{mmol} / 1$ Tris- $\mathrm{HCl}, \mathrm{pH} 8.3,50 \mathrm{mmol} / 1$ $\mathrm{KCl}, 1.5 \mathrm{mmol} / 1 \mathrm{MgCl}_{2}, 50 \mu \mathrm{mol} / 1$ of each dATP, dCTP, dGTP, dTTP, $1 \mu \mathrm{mol} / 1$ of each primer, 2 U Taq DNA polymerase, and $0.44 \mu \mathrm{g}$ TaqI Polymerase Start antibody. The initial denaturing was performed at $94^{\circ} \mathrm{C}$ for five minutes and then followed by 35 cycles of $94^{\circ} \mathrm{C}$ for 30 seconds, $68^{\circ} \mathrm{C}$ for 30 seconds, and $72^{\circ} \mathrm{C}$ for one minute; the final extension was at $72^{\circ} \mathrm{C}$ for seven minutes. PCR product $(16 \mu \mathrm{l})$ was digested using $8 \mathrm{U} H p h \mathrm{I}$ in a $24 \mu \mathrm{l}$ total volume containing $50 \mathrm{mmol} / 1$ potassium acetate, $20 \mathrm{mmol} / 1$ Tris-acetate, $10 \mathrm{mmol} / 1 \mathrm{mag}$ nesium acetate, $1 \mathrm{mmol} / \mathrm{l}$ dithiothteitol $(\mathrm{pH}$ 7.9) at $37^{\circ} \mathrm{C}$ for 12 hours. The digested samples were run on a mini non-denaturing gel containing $8 \%$ acrylamide and $15 \%$ glycerol at 170 volts and room temperature for one hour. The gel was stained in a $0.5 \mu \mathrm{g} / \mathrm{ml}$ ethidium bromide solution for five minutes and a gel picture was taken using an AlphaImager 2000 (Alpha Innotech Corporation, California).

CELL CULTURE AND RNA ISOLATION

Amniocytes were maintained in MEM (Sigma) supplemented with $20 \%$ fetal bovine serum and $1 \%$ penicillin/streptomycin (Gibco). When the number of the cultured cells reached 5 million, isolation of the total RNA was accomplished using Rneasy mini kit (Qiagen).

CDNA PREPARATION AND RT-PCR

The total RNA was treated with DNase I before the reverse transcription (RT) reaction. The RT reaction was performed using $5 \mu \mathrm{g}$ DNase I treated total RNA containing 20 $\mathrm{mmol} / \mathrm{l}$ Tris- $\mathrm{HCl}$ (pH 8.4), $50 \mathrm{mmol} / 1 \mathrm{KCl}, 2.5$ $\mathrm{mmol} / 1 \mathrm{MgCl}_{2}, 0.5 \mathrm{mmol} / 1$ of each $\mathrm{dNTP}, 0.01$ mol/1 DDT, $250 \mathrm{ng}$ random hexamer primers, and 200 units of SuperScript II reverse transcriptase (Gibco BRL). The reaction conditions were according to the manufacturer's instructions.

cDNA mix $(2 \mu \mathrm{l})$ from the RT reaction was used for RT-PCR in a $50 \mu \mathrm{l}$ volume. The PCR reaction contained $10 \mathrm{mmol} / \mathrm{l}$ Tris- $\mathrm{HCl}(\mathrm{pH}$ 8.3), $1.5 \mathrm{mmol} / 1 \mathrm{MgCl}_{2}, 50 \mathrm{mmol} / \mathrm{KCl}, 0.2$ $\mathrm{mmol} / \mathrm{l}$ each dATP, dCTP, dGTP, dTTP, 1 $\mu \mathrm{mol} / 1$ primers of L5-10f (5'CCTCCGACAACCACTCAGACTACA3') and L510r (5'CGGTTGCGGGCCTCACATT3'), $0.66 \mu \mathrm{g} T a q$ polymerase start antibody, and $3 \mathrm{U}$ Taq polymerase (Boehringer Mannheim). The PCR conditions were as follows: denature at $90^{\circ} \mathrm{C}$ for five minutes followed by 35 cycles of denature at $94^{\circ} \mathrm{C}$ for 30 seconds, annealing at $62^{\circ} \mathrm{C}$ for one minute and extension at $72^{\circ} \mathrm{C}$ for two minutes; the final extension was at $72^{\circ} \mathrm{C}$ for 10 minutes. The PCR products were run on $1.2 \%$ agarose gel containing $0.5 \times \mathrm{TBE}$ buffer and $0.5 \mu \mathrm{g} / \mathrm{ml}$ ethidium bromide.

\section{Results}

MUTATION ANALYSIS

The L1CAM gene was screened for mutations using DNA from the proband in family K8715 (IV.1, fig 1A). Restriction endonuclease fingerprint (REF) analysis was used for 19 of the 28 exons. ${ }^{813}$ This method involved amplifying the 19 exons in five clustered groups: $5-6,7-10$, $11-14,16-18,20-24 .^{8} \mathrm{REF}$ analysis showed a fingerprint pattern consistent with an alteration in exon 8 (fig 2A). Sequence analysis of exon 8 detected a $\mathrm{C} \rightarrow \mathrm{T}$ transition at position 924 (fig 2B). This base substitution occurred in the third base in codon 308 which encodes a glycine, thereby creating a neutral mutation 


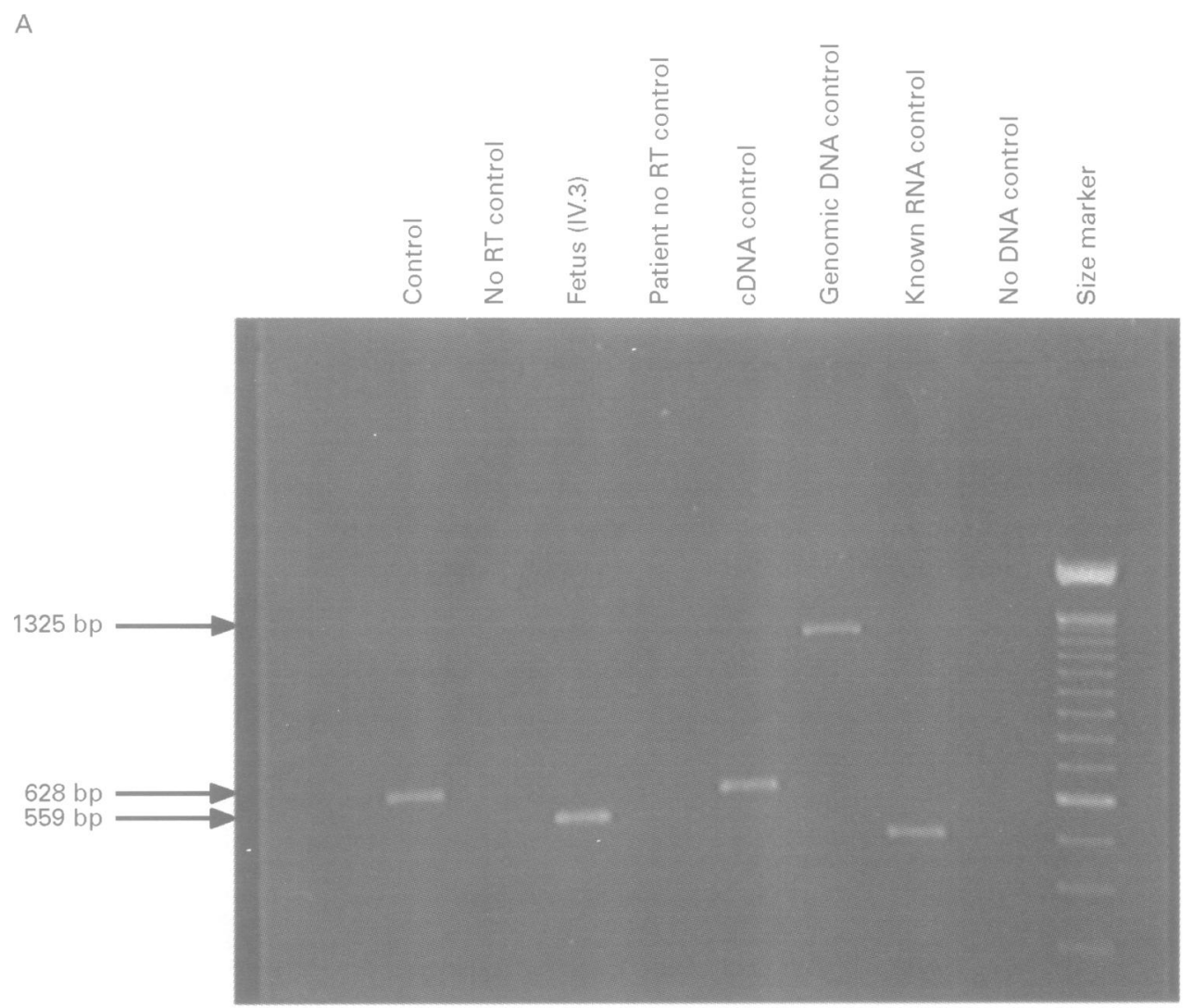

$B$

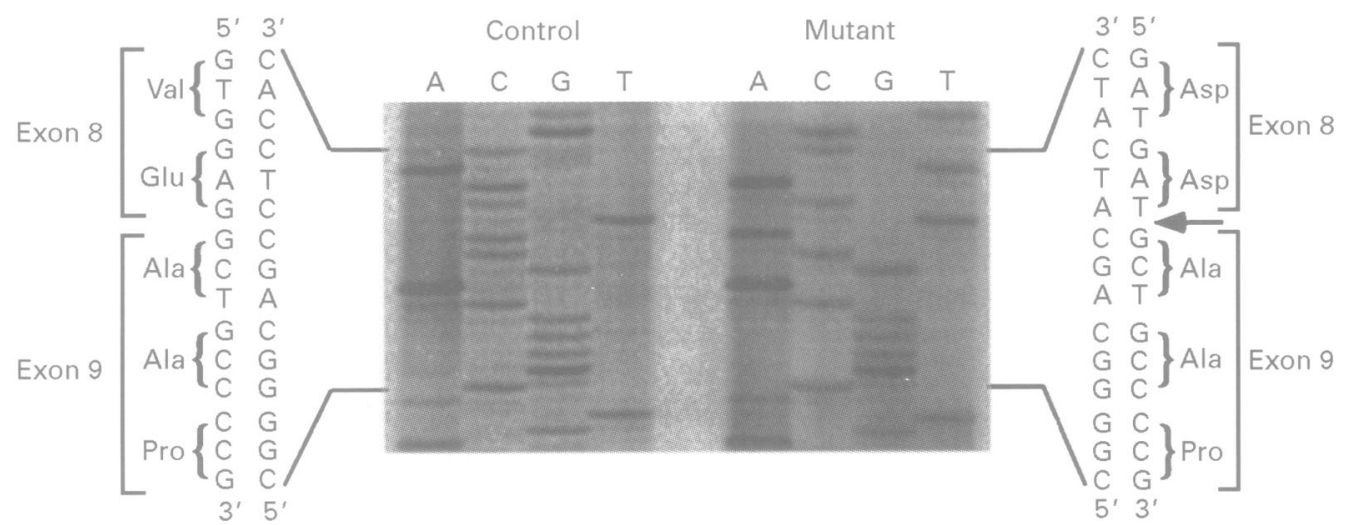

Figure 4 RT-PCR analysis of exons 6-10 of the L1CAM cDNA from amniocytes from the affected fetus (IV.3, fig $1 A$ ). (A) Agarose gel electrophoresis of RT-PCR products generated from a control (lane 1), the fetus (lane 3), and a cDNA library (lane 5), using primers given in Materials and methods. Lane 7 is the PCR product generated using genomic DNA as a template. Lane 8 is a product generated using primers and $R N A$ supplied with the SuperScript II reverse transcriptase kit (Gibco BRL) which was used as a positive control for the RT-PCR reactions. (B) Sequence analysis of the RT-PCR product from a control sample (left panel) and the affected fetus (right panel). The arrow in the right panel indicates the location of the $69 \mathrm{bp}$ deletion in the $m R N A$ from the affected fetus.

(G308G). The base substitution, however, did create a new $H p h I$ site. Analysis of the family showed that the presence of the site segregated with the HSAS (fig 1B). This was consistent with the previous haplotype analysis (data not shown).

The remaining nine exons $(1-4,19,25-28)$ with their flanking intronic sequences were examined using SSCP. No sequence alterations were detected after duplicate analyses (data not shown).
THE C924T (G308G) ALTERATION AS A MUTATION While the family was still being investigated, III. 2 became pregnant. Amniocentesis showed the fetus to be a male (IV.3, fig 1A). Analysis of DNA isolated from the amniocytes indicated the $\mathrm{X}$ chromosome of the fetus carried the at risk haplotype (data not shown) and the $H p h \mathrm{I}$ restriction site (fig 1B). Ultrasound at 23 weeks' gestation indicated borderline to mild ventriculomegaly. Physical examination of the fetus after delivery at 24 weeks showed relative 
macrocephaly and clasped thumbs. Necropsy was refused. Based on these clinical features and the absence of any other identified sequence alteration in the LICAM gene, the DNA sequence encompassing the C924T alteration was re-examined. Re-examination of the sequence showed that the $\mathrm{C} \rightarrow \mathrm{T}$ transition appeared to create a potential 5 ' splice site 69 bp upstream from the normal exon 8 /intron 8 splice site (fig 3 ). The new consensus sequence (TGgtgagt) had a consensus value of 0.88 while the normal splice site (GGgtatgg) had a value of $0.76 .{ }^{14}$ In theory, the new 5 ' splice site would possibly result in $69 \mathrm{bp}$ being eliminated from the mRNA (fig 3B). Furthermore, the absence of the $H p h I$ polymorphism in $200 \mathrm{X}$ chromosomes indicated that this alteration was not a common polymorphism in the normal population.

Based on these findings and assumptions, RT-PCR was performed on total RNA isolated from amniocytes of IV.3 using primers designed to amplify exons 6-10 in L1CAM mRNA. The results, presented in fig $4 \mathrm{~A}$, showed a band estimated to be about $559 \mathrm{bp}$ while the band amplified from control L1CAM mRNA contained the expected band of $628 \mathrm{bp}$. Thus, $69 \mathrm{bp}$ were apparently missing from the L1CAM transcript of IV.3 as predicted. Direct sequencing of the amplified fragment from IV.3 showed that the deletion involved the last $69 \mathrm{bp}$ of exon 8 (fig 4B).

\section{Discussion}

Sequence analysis of exon 8 of L1CAM in a family with HSAS indicated a single difference between the proband's exon and the normal L1CAM exon 8, a thymine substituted for a cytidine (C924T). Both the normal codon 308 (GGC) and the proband's codon 308 (GGT) encode for glycine. This silent nucleotide substitution was not found to be a common variant in the normal population. In fact, this neutral mutation resulted in the activation of a new splice site 69 bp 5 ' to the normal exon 8/intron 8 donor splice site (fig $3 \mathrm{~B}$ ), and segregated exclusively with HSAS in affected subjects and carriers in the family. The alternatively spliced mRNA codes for a L1CAM protein in which 23 amino acids (residues 308-330) are missing from the third Ig domain. ${ }^{15}$ This effectively eliminates the third near $\beta$ sheet of the domain, undoubtedly severely affecting the activity of the L1CAM protein and its ability to induce neurone-neurone adhesion. ${ }^{16}{ }^{17}$

This mutation is notable for two reasons. First, the mutation differs from other splice site mutations in L1CAM and other genes that give rise to a pathogenic phenotype as it neither destroys the function of a normal splice site nor creates a new splice site within an intron. ${ }^{6}{ }^{18} \mathrm{~A}$ review of published reports found that mRNA splicing mutations account for $15 \%$ of all point mutations causing human genetic disease ${ }^{18}$ Of these, $87 \%(88 / 101)$ are point mutations within either the $5^{\prime}$ or $3^{\prime}$ splice site consensus sequence. The remaining point mutations (13\%) lead to creation of novel splice sites. ${ }^{18}$ Thus, the creation of a novel splice site resulting from the C924T transition in exon 8 in our family is representative of a very rare mutational event that accounts for about $2 \%$ of all point mutations.

The second feature of the C924T mutation in L1CAM is perhaps more important. The point mutation in codon 308 in our family is a classic case of a neutral or silent mutation since the normal codon (GGC) and the variant codon (GGT) both encode for glycine. To our knowledge, there have been at least six other reports of silent mutations giving rise to a pathogenic phenotype. Goldsmith et $a l^{19}$ reported a $\mathrm{T} \rightarrow \mathrm{A}$ substitution in codon 24 of the $\beta$ globin gene that did not alter the amino acid as both normal and variant codon encoded for glycine. Using a gene expression system, the authors proved that the substitution caused abnormal mRNA splicing in a patient with $\beta$ thalassaemia. ${ }^{19}$ The second report was of an $A \rightarrow G$ substitution in the third position of a lysine codon of the factor IX gene in a patient with haemophilia $\mathrm{B} .{ }^{20}$ Although the altered sequence had a splice donor consensus value of 1.00 , the authors did not prove that alternate mRNA splicing occurred in their patient. As no other mutation was found, the authors presumed the silent $A \rightarrow G$ substitution to be pathogenic. ${ }^{20}$ Baumbach et $a l^{1}$ reported a neutral mutation $(\mathrm{C} 766 \mathrm{~T})$ in the third position of codon 236 of the growth hormone receptor (GH-R) gene. The mutation was shown to create a cryptic splice site $63 \mathrm{bp} 5^{\prime}$ to the normal exon 7 splice site, thereby eliminating 21 amino acids from the GH-R. Homozygosity for this mutation results in Laron's syndrome in a genetic isolate in the Bahamas. ${ }^{21}$ A neutral G to A transition in the third position of the alanine at codon 344 (A344A) in FGFR2 (fibroblast growth factor receptor II) has been observed in four unrelated Crouzon syndrome patients. ${ }^{22-25}$ Reardon $e t a l^{2}$ thought this base substitution would result in a new acceptor splice site. Jabs et $a l^{3}$ suggested the mutation could create either an acceptor or donor splice site. Recently, Li et $a l,{ }^{24}$ using RT-PCR and RNA isolated from cell cultures of their affected subject, showed that the A344A mutation created a new donor splice site. This finding was confirmed independently by Del Gatto and Brethnach $^{25}$ using cloned genes in cultured $\mathrm{HeLa}$ cells. Richard and Beckman ${ }^{26}$ found a silent $C \rightarrow T$ substitution in codon 624 of the calpain gene (CANP3) in a homozygous patient from one family with limb girdle muscular dystrophy (LGMD2A). Analyses of illegitimate transcripts showed an abnormal product which, upon sequencing, was found to be missing the last 44 bases of exon 16. Thus, this neutral mutation results in the gain of a new donor splice site. Lastly, a synonymous substitution (G2142A; S649S) in exon 11 presumably created a new acceptor splice site giving rise to a truncated RET proto-oncogene protein in members of a family with Hirschsprung disease. ${ }^{27}$

Most certainly the C924T mutation in L1CAM would have appeared as an altered transcript using RT-PCR. Indeed, at least two neutral mutations have been detected in this manner, both involving the XNP gene in two 
unrelated male patients with the ATR-X syndrome. ${ }^{28}{ }^{29}$ In neither paper, however, was the "neutral" nature of the mutation stressed since the method of detection involved RTPCR. Unfortunately, in many instances, use of genomic DNA rather than mRNA is better suited for mutational analysis. For one thing, a cell line is not always available for a dead proband while DNA may have been obtained at some time before death. Second, not all genes are expressed in lymphocytes which are the most readily accessible source of mRNA. ${ }^{30}{ }^{31}$ Finally, some genes are quite large, making it difficult if not problematical to obtain full length mRNA for analysis.

The silent mutation in L1CAM that was identified in our family with HSAS has enormous implications for mutation screening in any gene. The concept of a synonymous or neutral mutation should be altered when one is screening a candidate gene for disease causing mutations. A neutral base substitution can clearly have a profound effect on mRNA splicing or even codon usage, even though the nucleotide replacement is irrelevant with respect to the amino acid encoded by the codon. Thus, it would be wise to remember the words of Sherlock Holmes: "We must fall back upon the old axiom that when all other contingencies fail, whatever remains, however improbable, must be the truth." ${ }^{32}$

We thank the members of the family for their cooperation and interest in our research on L1CAM. Retecher Nelson prepared the RNA from the amniocytes and Chang-Yan Zou prepared the genomic DNA. Karen Buchanan typed the manuscript. This work was supported, in part, by a grant from the SC Department of Disabilities and Special Needs.

1 Rosenthal A, Jouet M, Kenwrick S. Aberrant splicing of neural cell adhesion molecule L11 mRNA in a family with X-linked hydrocephalus. Nat Genet 1992;2:107-12.

2 Willems P, Dijkstra I, Van der Auwera B, et al. Assignment of $\mathrm{X}$-linked hydrocephalus to $\mathrm{Xq28}$ by linkage analysis. Genomics 1990;8:367-70.

3 Jouet M, Feldman E, Yates J, et al. Refining the genetic location of the gene for X linked hydrocephalus within Xq28. tion of the gene for X linked hen 1993;30:214-17.

4 Rathjen F, Schachner M. Immunocytological and biochemical characterization of a new neuronal cell surface compocal characterization of a new neuronal cell surface component (L1 antigen) whic

5 Jouet M, Rosenthal A, Armstrong G, et al. X-linked spastic paraplegia (SPG1), MASA syndrome and X-linked hydrocephalus result from mutations in the $\mathrm{L} 1$ gene. Nat Gene 1994;7:402-7.

6 Vits L, Van Camp G, Coucke P, et al. MASA syndrome is due to mutations in the neural cell adhesion gene L1CAM. Nat Genet 1994;7:408-13.

7 Van Camp G, Fransen E, Raes G, Willems P. L1 mutation web page http://alt-www.uia.ac.be/u/dnalab/11.html 1996.

$8 \mathrm{Du}$ YZ, Srivastava AK, Schwartz CE. Multiple exon screening using restriction endonuclease fingerprinting (REF): ing using restriction endonuclease fingerprinting (REF): detection of six novel mutations in the $L 1$ cell adhesion molecular (L1CAM) gene. Hum Mutat 1998;11:222-30.

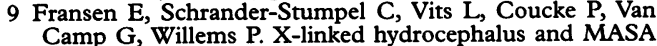

syndrome present in one family are due to single missense mutation in exon 28 of the LiCAM gene. Hum Mol Gene 1994;3:2255-6.

10 Fryns J, Spaepen A, Cassiman J, Van den Berghe H. X linked complicated spastic paraplegia, MASA syndrome, and $\mathrm{X}$ linked hydrocephalus owing to congenital stenosis of the aqueduct of Sylvius: variable expression of the same mutation at Xq28. ₹ Med Genet 1991;28:429-31.

11 Schwartz CE, Ulmer J, Brown A, Pancoast I, Goodman HO, Stevenson RE. Allan-Herndon syndrome. II. Linkage to Stevenson RE. Allan-Herndon syndrome. II. Linkage

12 Patterson M, Schwartz C, Bell M, et al. Physical mapping studies on the human $\mathrm{X}$ chromosome in the region Xq27Xqter. Genomics 1987;1:297-306.

$13 \mathrm{Liu} \mathrm{Q}$, Sommer S. Restriction endonuclease fingerprinting (REF): a sensitive method for screening mutations in long, contiguous segments of DNA. BioTech 1995;18:402-7.

14 Cooper D, Krawczak M. Are splice sites involved in mutations representative of the "average" splice site? In: Human gene mutation. UK: BIOS Scientific Publishers Human gene mutation

15 Hlavin M, Lemmon V. Molecular structure and functional testing of human LICAM: an interspecies comparison Genomics 1990;11:416-23.

16 Bateman A, Jouet M, Macfarlane J, Du J, Kenwrick S, Chothia C. Outline structure of the human L1 cell adhesion molecule and the sites where mutations cause neurological disorders. EMBO $\mathcal{F}$ 1996;15:6050-9.

17 Takechi T, Tohyama J, Kurashige T, et al. A deletion of five nucleotides in the L1CAM gene in a Japanese family with X-linked hydrocephalus. Hum Genet 1997:3:353-6.

18 Krawczak M, Reiss J, Cooper D. The mutational spectrum of single base-pair substitutions in mRNA splice junctions of single base-pair substitutions in mRNA splice junctions of human genes:

19 Goldsmith M, Humphries R, Ley T, Cline A, Kantor J, Nienhuis A. "Silent" nucleotide substitution in a $\beta^{+}$ thalassemia globin gene activates splice site in codin sequence RNA. Proc Natl Acad Sci USA 1983;80:2318-22.

20 Koeberl D, Bottema C, Ketterling R, Bridge P, Lillicrap D Sommer S. Mutations causing hemophilia B: direct estimate of the underlying rates of spontaneous germ-line transitions, transversions, and deletions in a human gene. Am 7 Hum Genet 1990;47:202-17.

21 Baumbach L, Schiavi A, Bartlett R, et al. Clinical, biochemi$\mathrm{cal}$, and molecular investigations of a genetic isolate of $\mathrm{cal}$, and molecular investigations of a genetic isolate of growth hormone insensitivity (La
Endocrinol Metab 1997;82:444-51.

22 Reardon W, Winter RM, Rutland P, Pulleyn LJ, Jones BM, Malcolm S. Mutations in the FGFR-2 gene cause Crouzon syndrome. Nat Genet 1994;8:98-103.

23 Jabs EW, Li X, Scott AF, et al. Jackson-Weiss and Crouzon syndromes are allelic with mutations in FGFR-2. Nat Genet 1994;8:275-9.

$24 \mathrm{Li} \mathrm{X}$, Park WJ, Pyeritz RE, Jabs EW. Effect on splicing of a silent FGFR2 mutation in Crouzon syndrome. Nat Genet 1995;9:232-3.

25 Del Gatto F, Brethnach R. A Crouzon syndrome synonymous mutation activates a 5 ' splice site within the IIIC exon of the FGFR2 gene. Genomics 1995;27:558-9.

26 Richard I, Beckmann JS. How neutral are synonymous codon mutations? Nat Genet 1995;10:259.

27 Salomon R, Attié T, Pelet A, et al. Germline mutations of the RET ligand GDNF are not sufficient to cause Hirschsprung disease. Nat Genet 1996;14:345-7.

28 Picketts D, Higgs D, Bachoo S, Blake D, Quarrell O, Gibbons R. ATRX encodes a novel member of the SNF2 family of proteins: mutations point to a common mechanism underlying the ATR-X syndrome. Hum Mol Genet 1996;5:1899-907.

29 Villard L, Lossi A, Cardoso C, et al. Determination of the genomic structure of the XNP/ATRX gene, encoding a genomic structure of the XNP/ATRX gene, encos

$30 \mathrm{Gecz}$ J, Gedeon A, Sutherland G, Mulley J. Identification of Gecz J, Gedeon A, Sutherland G, Mulley J. Identification of tion. Nat Genet 1996;13:105-8.

$31 \mathrm{Gu}$ Y, Shen Y, Gibbs R, Nelson D. Identification of FMR2, a novel gene associated with the FRAXE CCG repeat and CpG island. Nat Genet 1996;13:109-13.

32 Conan Doyle A. The adventure of the Bruce-Partington plans. In: The works of Sir Arthur Conan Doyle, complete and unabridged. London: Longmeadow Press, 1984:803. 